\title{
Does Leisure Involvement Impact on Service Performance? Empirical Finding from the Indonesian Culinary Industry
}

\author{
Olivia Sri Kartika ${ }^{\mathrm{a}}$ and Zurinawati Mohi Mohyi ${ }^{\mathrm{b}^{*}}$ \\ ${ }^{\text {a }}$ Graduate, Departement of Business Administration, Politeknik Negeri Bandung, Indonesia \\ ${ }^{\mathrm{b}}$ Associate Professor, Faculty of Hotel and Tourism Management, Universiti Teknologi MARA, \\ Malaysia
}

Received 10 September 2018; accepted 21 January 2019

\begin{abstract}
Many studies have examined the frontline service staff performance of various industries but rarely found to be associated with leisure involvement in the culinary industry. This study discusses the relationship between leisure involvement and service performance with mediation of variables subjective to well-being and job satisfaction. The research model used is PLS or partial least squares modelling, by taking samples from the frontline staff of culinary industry which amounts to 313 samples in Bandung City, Indonesia. The results of this study show that there is a significant relationship between leisure involvement and service performance, as well as with the mediator. In conclusion, an employee who is often involved in leisure activities is likely to be happy and will result in his good performance in serving customers. This is also influenced by his satisfaction in work, although theresults are not too significant. The implication is that the management and businessmen need to pay greater attention to the welfare of employees should they wish to improve the service performance of their restaurants. This report is structured to meet one of the conditions for completing education.
\end{abstract}

\section{KEYWORDS}

Frontline staff

Culinary industry

Leisure involvement Job satisfaction

Service performance

\section{INTRODUCTION}

The culinary industry is a strategic sector for the economic development in Indonesia (Evani, 2017), and has become one of the fastest growing industries. Promising business opportunities have made the culinary industry as one of the economic supporters in the creative industry (Agmasari, 2018). Indonesia has various fields of creative industries, but the culinary industry has become one of the most powerful creative industries in the economy. The culinary industry has great potential to continue growing in Indonesia. Of the 8.2 million units of creative industries, 68 percent of them are in the culinary industry (Agmasari, 2018).

The main cause of the rapid development of this culinary business is due to the increasingly high lifestyles of the society. Indonesian consumers' spending on food and beverages in 2016 was recorded at USD 176.7 billion (Iuniman, 2017). Lifestyle of the community makes the restaurant not only a place to eat but also a place to gather with family, 
relatives, and friends with an emphasis on the atmosphere and quality of restaurants (MacLaurin, 2001). So it is necessary for efforts to further develop the culinary industry. This certainly requires the culinary industry players to always innovate and improve the quality of their service. One of them is by maximizing the culinary ecosystem of Indonesia from the aspect of human resources.

The Central Bureau of Statistics, BPS in the province of West Java (2018b) recorded that in 2016, the number of restaurants reached 2,853, and predicted to increase every year. In Bandung for example, restaurants are easily located. The number of eateries recorded by BPS Bandung (2018a) is 396 restaurants, 372 types of warung makan (food stall), 14 types of cafes, and 13 bars amounting to 795 restaurants. These figures proven that Bandung has a great contribution to the culinary development in West Java, Indonesia.

Business in restaurant is a business that provides goods as well as services. Service is the main highlight of such business(Long, 2004). The staff plays an important role in delivering the services offered. Employee performance will be a benchmark for consumers in giving a good assessment for the restaurant(Henderson, 2004). Particularly, frontline staff face direct encounter (face to face encounter) with customers who demand fast and efficient service, and this would also require their friendly attitude in helping and handling the customers. Based on the observations done by Lovelock and Wirtz (2011), frontline staff is a job which is typically underpaid, undertrained, overworked and highly stressed. Referring to this, stress is often experienced by frontline staff in the culinary industry.

It is important to understand and predict the performance of employees. If predicted from the perspective of employee wellbeing, mood can affect employees' performance (Lovelock \& Wirtz, 2011). In addition, job satisfaction is also an important factor in influencing whether they do their job well (Yeh, 2013). Therefore, employers need to get around how to maintain employees' performance in order to remain consistent. Additionally, Yeh (2013) claims that tourism involvement can be a driver of employees' performance.

This paper examines how leisure involvement, subjective wellbeing, and job satisfaction influence employee service performance. The purpose of this paper is to identify the direct effect of leisure involvement on service performance and indirect effect through subjective well-being and job satisfaction.

\section{THEORETICAL FRAMEWORK AND HYPOTHESES}

\section{Development of the Research Model}

This study aims to examine the impact of leisure time involvement on front-line staff performance. Based on the literature discussed in the following sub-sections, the research model is illustrated in Figure 1.

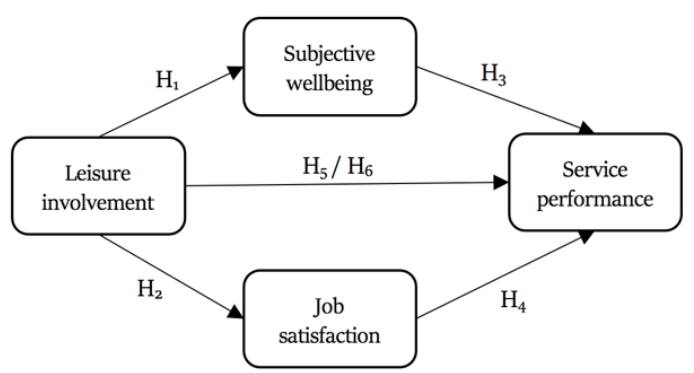

Figure 1. The proposed model 


\section{Service Performance}

Service is essentially an action from one party to the other with the aim of helping, or the existence of a request to another party to meet their needs. In business, service is an aspect that cannot be underestimated in competition. Liao and Chuang (2004) believe that service performance is achievable by group or an organization with the authority and responsibility of each to achieve business goals. Bowen and Ford (2004) however, argue that for employees to serve customers well, companies need to motivate and satisfy the employee so that they can provide services without any difficulty. There is also a responsibility that is divided into three components (Borman \& Motowidlo, 1993) namely the Role, the Extra-role to clients and the Extra-role to the organization.

The first is Role. This component refers to the main tasks, including understanding the description of the job and the services to be delivered, performing the right product display, and handling receiving client orders (Borman \& Motowidlo, 1993). The second is Extra-role. This role is entirely from the management policy to treat the customer as it has been established, as well as by providing extra services to clients. This component can indirectly affect the value of services provided by the customer (Borman \& Motowidlo, 1993). The third is Extra-role to the organization. This component refers to the ability of employees to promote their organizations in a positive way that will change the customer's mindset (Borman \& Motowidlo, 1993).

\section{Leisure Involvement}

Involvement is a concept widely used by scientists lately in the science of consumer behavior associated with leisure, recreation and tourism (Havitz \& Dimanche, 1990a). Leisure is the free time available for someone to do the activities he enjoys(Rothschild, 1984). Leisure activities are done to make someone feel relaxed and happy. Therefore, to seek pleasure, a person usually performs leisure activities in his spare time (Havitz \& Dimanche, 1990a). In addition, leisure time can also be enjoyed together or done in private.

$\mathrm{Lu}$ and $\mathrm{Hu}$ (2016) reveal that leisure elements could be found in the outer sphere (outdoor) or indoor (indoor). Physical activities such as sports, outbound, or non-physical activities such as watching shows or listening to music, can be classified as leisure activities (Slatten \& Mehmetoglu, 2011). In general, people enjoy more of their free time than their job, because in their spare time they can do activities that make them happy.

According to a theory by Kyle and Mowen (2005), leisure involvement has three dimensions namely; attraction, centrality, and identity expression. These three mentioned dimensions represent the conceptual aspects of leisure involvement. The attraction dimension is a combination of the concept of interest and pleasure in leisure activities. Owned views should not concern about how often a person engages in leisure activities, but rather on how he enjoys and demonstrates the activities performed (Kyle, Absher, Norman, Hammitt, \& Jodice, 2007). The next one is centrality. Leisure activities definitely lead to one's lifestyle (Watkins, 1986). Within the dimension of centrality, some things relate to an individual, such as the revelation of the role in life and how to anticipate it. The dimension of identity expression, on the other hand, refers to the representation of self that wants to be shared with others to join them (Laurent \& Kapferer, 1985). This leads more to someone who wants to show his/her identity to others and tries to persuade.

A previous study from Yeh (2013), on the relationship of tourism involvement with job satisfaction which is mediated by work engagement variable, shows a positive influence on job satisfaction. Suhartanto and Brien (2018) who also investigate the relationship of tourism 
involvement with service performance, find that leisure involvement has an effect on service performance by being mediated by work engagement and job satisfaction.

The results of previous study from Jernej and Mussap (2010) which focus on the effect of leisure on subjective wellbeing have shown a positive effect. Therefore, the following hypotheses are formulated:

$\mathrm{H}_{1}$ : Leisure involvement positively and significantly influences subjective wellbeing $\mathrm{H}_{2}$ : Leisure involvement positively significantly influences job satisfaction $\mathrm{H}_{5}$ : Leisure involvement directly positively and significantly influences service performance $\mathrm{H}_{6}$ : Leisure involvement indirectly positively and significantly influences service performance

\section{Subjective Wellbeing}

Subjective wellbeing is a broad concept that includes some negative and positive aspects of a person or individual. These issues are related to their lives, including work, family, and health, which consist of a scientific analysis of how one evaluates their lives (Dimanche, Havitz, \& Howard, 1993). Often the components of subjective wellbeing are correlated with each other (DeNeve \& Cooper, 1998) so they are researched into one construct, but the research shows that the subjective wellbeing component is a separate construction (Lucas, Clark, Georgellis, \& E, 2003).

Based on Personal Wellbeing Index (2008), there are some important components or dimensions to achieve in life. First is the view about the current life whether it is good. The second is a standard of living. It is about the statements that lead to the reference it has to assess the lives of individuals. The third is health, which is about the statement of living a healthy life. The fourth is safety which refers to the sense of security. The fifth is achievement in life which is a statement about the targets achieved so far. Finally, the last component is the future security. It's about the guarantee of life in the future whether it has been well planned.

Previous studies had focused on the influence of the demographic factors. One of the studies found that marriage and income are the factors that affect subjective wellbeing (Jernej \& Mussap, 2010). Although subjective wellbeing has been widely studied in the field of psychology, it is rarely discussed in marketing area. For example, there is little understanding on how subjective wellbeing affects employee service behavior. Therefore, this study involves the subjective wellbeing variable in examining the relationship of leisure involvement with service performance.

$\mathrm{H}_{3}$ : Subjective wellbeing positively and influences service performance

\section{Job Satisfaction}

Locke (1969) defines job satisfaction as an emotional state that has a positive side generated by an individual's experience associated with his work. An employee who may be dissatisfied with his or her job will have the desire to quit his job. There are also important factors that encourage job satisfaction, such as the activities undertaken during work, and the background or reputation of the company that becomes a pride for the employees (Hoy \& Miskel, 1996). The statement is also supported by spillover theory which proposes the characteristics of work activities and organizational characteristics as factors that support job satisfaction.

Generally, employees expect and gain satisfaction from their workplace. Kreitner and Kinicki (2014) reveal that job satisfaction is a form of emotional response of a person to the work aspect. More briefly, it is a feeling of pleasure or unpleased towards their work. Naturally, every 
individual has a different level of satisfaction. A study conducted by Yeh (2013) shows that there are two important elements in job satisfaction, namely the value of work values and basic needs.

The relationship of satisfaction with service performance is often debated in previous research because of the varied results obtained (Suhartanto \& Noor, 2012). Although some studies suggest that the relationship of job satisfaction has a positive effect with a low value, a few studies prove the high value of influence. The reverse relationship is that factors employees are satisfied with their work due to their high performance. But in general, an employee who may be dissatisfied with his work will get the desire to quit his job. Meanwhile, employees who are satisfied with their work tend to show good attitude and behavior towards their work (Saks, 2006).

To confirm the findings of previous research, the job satisfaction variable will be taken into consideration to examine relationship involvement and service performance. Some of the indicators used to test employee job satisfaction are the desire to keep the current job, consideration of resigning (Liao \& Chuang, 2004) from the current job, the overall satisfaction with the job, and an attempt to look for another job as a substitute.

$\mathrm{H}_{4}$ : Job satisfaction positively and significantly influences service performance

\section{RESEARCH METHOD}

To achieve the objectives of this study, both primary and secondary data were analyzed. Data were collected from frontline staff working in the culinary field in Bandung. The focus of this research was on the performance of services provided by frontline culinary staff. Based on statistical data there were 795 restaurants listed in Bandung, covering 396 specialty restaurants, 372 restaurants, 14 cafes, and 13 bars (Indonesia, 2016). Data were collected from 48 carefully selected culinary types taking into account the size of the culinary place (see a table of culinary characteristics). Respondents were selected randomly from the selected culinary place and were asked voluntarily to participate in the study. They were first provided with adequate instructions to fill in the questionnaire and later were informed of the confidentiality of their responses. Of the 332 employee responses collected, only 313 responses were used for further analysis because 19 responses were not filled in entirely. Based on Hair et al. (2014) s' contention on adequate sample size in using SEM-PLS is at least ten responses can be shown for each item, so based on the minimum requirement, it was recommended that the sample size for this study was 290 . However larger sample sizes will increase consistency (Hair et al., 2014). Therefore, 313 responses gathered are suitable to test the proposed model.

The current research used several items to measure the frontline staff construction variables in the culinary field. The research questionnaire was developed based on the existing literature. Leisure involvement was measured by 12 items formed from three dimensions that represent attraction, centrality and identity expression adapted from Kyle \& Mowen's theory (Kyle \& Mowen, 2005). The study was linked to the subjective well-being with life as a whole, the standard of living, health, achievement in life, how safe you feel, and future security as dimensions by adapting from previous research conducted by Jernej and Mussap (2010). For the scale of service performance, it was measured by using five items which were adapted from previous research (Borucki \& Burke, 1999) and also from study literature (Liao \& Chuang, 2004). All indicators in the variable were measured using a Likert scale consisting of 5 points as fair value ( 1 = strongly disagree, 2 = disagree, 3 = neutral, 4 = agree, $5=$ strongly agree). The questionnaire was tested by pre-testing the first ten frontline staff to ensure clarity and suitability of questions. 


\section{RESULTS}

Table 1 and Table 2 summarize the respondent's description of the data collected. Table 1 shows the characteristics of respondents, while the Table 2 shows the characteristics of the culinary place.

\section{Measurement Model}

The next step is to conduct the validity and reliability of the questionnaire to ensure the accuracy of the questions or statements on each variable given to the respondents in this study.

To measure the validity of the instrument, factor loadings and average variance extracted (AVE) was used. Based on the results of validity tests conducted on the variable leisure involvement, subjective wellbeing, job satisfaction, and service performance, it can be seen in Table 3 loading of item management, items are declared valid and reliable if the value is above the cut-off value (more than 0.5) (Anderson \& Gerbing, 1988). So it can be concluded that all items are declared valid because the value owned is more than 0.5. Next is AVE which produces various values. All the variables tested shows that the results above the cut-off value (greater than 0.5 ) are 0.501 for leisure involvement variables, 0.502 for variables subjective wellbeing, 0.718 for job satisfaction variables, and 0.631 for service performance. The values are more than minimum, so it can be concluded that the value of the questions tested to measure the valid variable is valid.

The next test is reliability test on each variable used in this study. This test was conducted with the aim to test the consistency of each variable. The results of the reliability test performed can be found in Table 3 in the Cronbach's alpha and composite reliability (CR) columns. It shows that all variables have Cronbach's alpha and CR are above from the cut-off value of o.6 (Hair \& Sarstedt, 2014). So, it can be deduced that the overall variables used in this study were reliable or consistent as a measuring tool.

Another way to test convergent validity is based on the Heterotroit-Monotrait ratio of correlation (HTMT) in Table 4 as proposed by Henseler, et al. (2009). The construct is discriminant validity if the value of HTMT owned is smaller than 0.850 and the confidence interval value is less than 1.o. The results of the analysis contained in Table 4 shows that the value of HTMT and confidence interval owned by each variable is below the cut-off value $(<0.850)$. It can be concluded that the variables are valid and now can analyzed in the next stage.

\section{Structural Model}

Based on the theory described by Hair and Sarstedt (2014) the bootstrap method performed in SmartPLS is done to assess the significance of the indicator. Next, the value of the goodness of fit (GOF) is determined to find out how well the performance of the respective variables in the research model. There is also a standard provision for GOF results divided into three categories. The first one is starting from "small" if the value is about 0.02 , the second is "medium" if the value is about 0.25 , and the third is "big" if the value is about 0.36 (Hair \& Sarstedt, 2014). The GOF research value obtained is 0.387 . It can be concluded that the research model of the relationship between leisure involvement and service performance has a large level and so it shows the model has a good performance. 
Table 1. Characteristic of the respondents

\begin{tabular}{llc}
\hline Demographic & Description & Frequency \\
\hline \multirow{2}{*}{ Gender } & Male & 163 \\
& Female & 150 \\
Age & 18-24 years old & 219 \\
& 26-35 years old & 78 \\
& 36-45 years old & 15 \\
& $>$ 45 years old & 1 \\
\multirow{3}{*}{ Education } & - High School & 71 \\
& High school & 206 \\
& Bachelors & 35 \\
Working & Magister & 1 \\
experience & 3 3 years & 217 \\
& $>$ 10years & 92 \\
\hline
\end{tabular}

Table 2. Restaurant characteristics

\begin{tabular}{llc}
\hline Variable & \multicolumn{1}{c}{ Description } & Frequency \\
\hline \multirow{3}{*}{ Store size $\left(\mathrm{M}^{2}\right)$} & $<10$ & 59 \\
& $11-25$ & 146 \\
& $>25$ & 108 \\
Number of & $<3$ & 40 \\
staff & $3-10$ & 146 \\
& $>10$ & 127 \\
Consumers & $<25$ & 9 \\
visit average & $26-50$ & 102 \\
& $>50$ & 203 \\
& Cafe & 84 \\
Types of & Restaurant & 121 \\
restaurant & Food court & 6 \\
& Food stall & 55 \\
& Others & 47 \\
\hline
\end{tabular}

According to the opinion of Chi and Gursoy (2009) that the values of $\mathrm{R}^{2}$ and Stone-Geisser (Q2) are used as a significant analysis to assess the research model using the PLS. So in this study the value of Q2 cannot be ignored and must be proven. The result of Q2 obtained for subjective variable is 0.087 , job satisfaction is 0.049 , and service performance is 0.287 . It can be concluded that the three variables have satisfactory relevance prediction(Hair \& Sarstedt, 2014). Furthermore, the result of $\mathrm{R}^{2}$ is the result of testing of structural model. It is seen that leisure involvement which is $19.1 \%\left(\mathrm{R}^{2}=0.191\right)$ in this research affects subjective wellbeing, while $8.1 \%$ $\left(\mathrm{R}^{2}=0.081\right)$ job satisfaction variable is influenced by leisure involvement, and $49.3 \%\left(\mathrm{R}^{2}=0.493\right)$ service performance variable is influenced by leisure involvement.

Table 4. Heterotrait-Monotrait ration (HTMT)

\begin{tabular}{lccc}
\hline & 1 & 2 & 3 \\
\hline 1. Job satisfaction & & & \\
2. Leisure involvement & 0.365 & & \\
3. Subjective well-being & 0.823 & 0.481 & \\
4. Service performance & 0.652 & 0.632 & 0.644 \\
\hline
\end{tabular}


Table 3. Loading of the item measurement, composite reliability (CR) and AVE

\begin{tabular}{|c|c|c|c|c|}
\hline Construct/item & * & $\alpha$ & $\mathrm{CR}$ & AVE \\
\hline Leisure involvement & & 0.910 & 0.923 & 0.501 \\
\hline Leisure is very important & 0.765 & & & \\
\hline Leisure offers relaxation when pressures build up & 0.703 & & & \\
\hline Participating in leisure is one of the most satisfying things & 0.740 & & & \\
\hline Enjoying leisure & 0.721 & & & \\
\hline Life is organized around leisure & 0.684 & & & \\
\hline Leisure has a central role in my life & 0.719 & & & \\
\hline Discussing leisure with friends & 0.721 & & & \\
\hline Participating in leisure provides with opportunity to be with friends & 0.692 & & & \\
\hline Participating in leisure. says a lot about whom I am & 0.765 & & & \\
\hline Could tell a lot about a person by seeing them participating in leisure & 0.583 & & & \\
\hline When participate in leisure can be yourself & 0.725 & & & \\
\hline When participate in leisure others see me the way they want to see me & 0.654 & & & \\
\hline Subjective well-being & & 0.801 & 0.858 & 0.502 \\
\hline Life as a whole & 0.773 & & & \\
\hline Standard of living & 0.694 & & & \\
\hline Health & 0.618 & & & \\
\hline Achievements in life & 0.764 & & & \\
\hline How safe you feel & 0.736 & & & \\
\hline Future security & 0.655 & & & \\
\hline Job satisfaction & & 0.608 & 0.836 & 0.718 \\
\hline Overall satisfaction with current job & 0.840 & & & \\
\hline Intention to keep the current job in the future & 0.856 & & & \\
\hline Service performance & & 0.902 & 0.923 & 0.631 \\
\hline Being friendly and helpful to customers quickly & 0.774 & & & \\
\hline Approaching customers quickly & 0.843 & & & \\
\hline Asking good questions a listening to find out what a customers want & 0.862 & & & \\
\hline Being able to help customer's when needed & 0.778 & & & \\
\hline Pointing out and relating item' features to a customer's needs & 0.787 & & & \\
\hline Suggesting items customers might like but didn’t think of & 0.709 & & & \\
\hline $\begin{array}{l}\text { Explaining an items' features and benefits to overcome a customer's } \\
\text { objections }\end{array}$ & 0.799 & & & \\
\hline
\end{tabular}

Table 5. Goodness of fit (GoF) index

\begin{tabular}{llll}
\hline \multicolumn{1}{c}{ Variable } & \multicolumn{1}{c}{ AVE } & \multicolumn{1}{c}{$\mathrm{R}^{2}$} & $\mathrm{Q}^{2}$ \\
\hline Leisure involvement & 0.501 & & \\
Subjective well-being & 0.502 & 0.191 & 0.087 \\
Job satisfaction & 0.718 & 0.081 & 0.049 \\
Service performance & 0.631 & 0.493 & 0.287 \\
Average score & 0.588 & 0.255 & \\
AVExR $^{2}$ & & 0.150 & \\
GoF $=\sqrt{ }$ AVExR $^{2}$ & & 0.387 & \\
\hline
\end{tabular}

The next analysis is path analysis. The results of the analysis can be seen in Table 6 based on the calculation of path coefficient. The information that can be taken is leisure involvement has a significant influence on service performance variable. In addition, the relationship between 
subjective wellbeing and job satisfaction towards leisure involvement is also significant. This is proven by the significance value for each relationship which is above the cut-off value ( $p>1.96)$.

Table 6. Path coefficient

\begin{tabular}{lrrrrrrr}
\hline \multirow{2}{*}{ Influence effect of variable } & \multicolumn{2}{c}{ Direct } & \multicolumn{2}{c}{ Indirect } & \multicolumn{2}{c}{ Total effect } \\
\cline { 2 - 7 } & $\beta$ & \multicolumn{1}{c}{$\mathrm{T}^{*}$} & $\beta$ & $\mathrm{T}^{*}$ & \multicolumn{1}{c}{$\beta$} & \multicolumn{1}{c}{$\mathrm{T}^{*}$} \\
\hline Leisure involvement -> Subjective wellbeing & 0.437 & 7.968 & - & - & 0.437 & 7.968 \\
Leisure involvement - Job satisfaction & 0.284 & 4.555 & - & - & 0.284 & 4.555 \\
Subjective wellbeing - > Service performance & 0.252 & 4.500 & - & - & 0.252 & 4.500 \\
Job satisfaction -> Service performance & 0.222 & 3.530 & - & - & 0.222 & 3.530 \\
Leisure involvement -> Service performance & 0.414 & 7.651 & 0.173 & 5.435 & 0.588 & 10.840 \\
\hline
\end{tabular}

*All significant $p<0.01$

If examined closely, all independent variables have a positive influence on the dependent variable because the value obtained is above the cut-off value ( $p>0.01)$ with either direct or indirect the relationship. To be specific, the influence of leisure involvement on subjective wellbeing is 0.437 with t-value 7.968, which means $\mathrm{H}_{1}$ is accepted. The influence of leisure involvement on job satisfaction, however, is 0.284 with t-value 4.555 which means leisure involvement directly, positively and significantly influences job satisfaction, and therefore $\mathrm{H}_{2}$ is accepted. For service performance variable, 0.252 is influenced by subjective wellbeing with tvalue 4.500, and 0.222 is influenced by job satisfaction with t-value 3.530, thus $\mathrm{H}_{3}$ and $\mathrm{H}_{4}$ are accepted. In addition, service performance is 0.414 directly influenced and 0.173 indirectly influenced by leisure involvement. It means the total effect is 0.588 with total $t$-value is 10.840 which shows leisure involvement directly and indirectly, positive and significantly influence service performance, Thus, $\mathrm{H}_{5}$ and $\mathrm{H}_{6}$ are accepted. The independent variable here is able to directly influence the dependent variable even without the involvement of the mediator, as it is shown by the value of the direct influence which is greater than the value of indirect effect. Thus all hypotheses are accepted.

\section{DISCUSSION}

The findings of this study support the findings of Jernej and Mussap (2010) which mentioned subjective wellbeing was contributed by leisure involvement. Other previous research also mentioned that leisure involvement influences service performance (Suhartanto et al., 2018) directly or through a mediator. It was earlier discussed that the influence given by each variable and job satisfaction variable has the least effect.

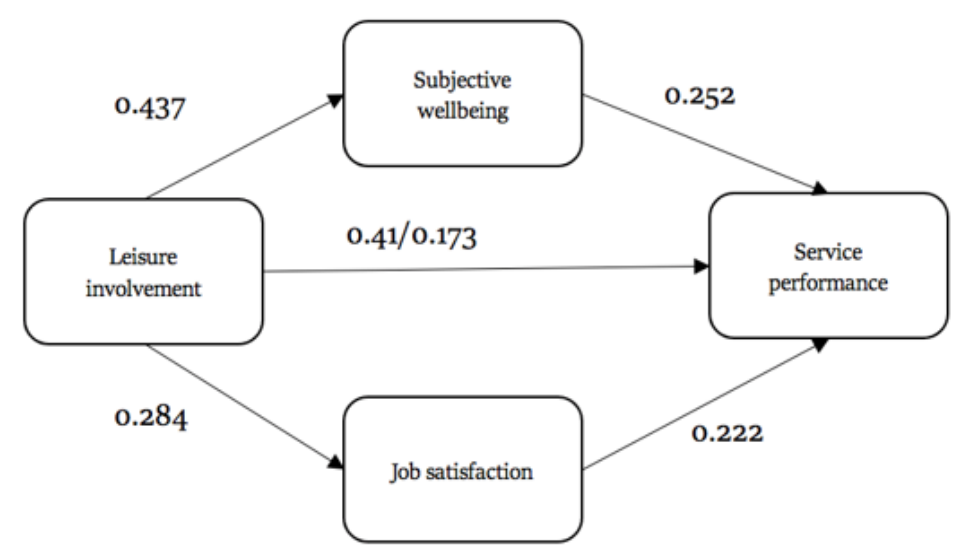

Figure 2. Result model 
The relationship between job satisfaction and tourism involvement has also been studied previously by Yeh (2013) which finds positive influence. The statement correlates with the current research. Tourism involvement is a derivation of leisure involvement. An understanding that can be taken is that leisure time is owned and it involves any activity of which the purpose is to satisfy the individual's pleasures built with attraction, centrality, and self-expression dimensions. Tourism itself is a psychological state of motivation or interest between the personal penchant with recreation and tourist destinations or other related things at a time (Havitz \& Dimanche, 199ob). In addition to these studies, these results are also increasingly convincing that the role of leisure involvement is important in a person's life. Leisure is felt necessary to achieve life satisfaction (Kyle \& Mowen, 2005).

From managerial point of view, a restaurant is a business that provides goods and services. In business the employee's service becomes an important key in business continuity, but the work of the frontline staff is demanding. They deal with customers and reach outer boundaries and they are demanded for quick and efficient work and at the same time have the courtesy in helping or dealing with customers. Frontline work is difficult and stressful, especially in high demanding, fast, and busy restaurant businesses. With the existing situation, staff will be easily depressed and stressed to get good service performance. At that time, leisure involvement can be a controller in improving service performance of frontline staff. Good service performance will satisfy customers and provide a good reputation for the restaurant (Hoffman \& Bateson., 2011). Based on a past study, the staff needs to take a break from the work routine (Jernej \& Mussap, 2010).

Leisure involvement has an influence on subjective variable wellbeing, meaning that by doing leisure activities, the staff will feel pleasure. The new findings in this study is also reflected by the importance of subjective wellbeing on employee service performance. The implication is that when the staff is happy and always in a good mood, they will bring positive vibes which leads to better work performance. Thus, the point is, by engaging in leisure activities, the staff will be out of routine work and focuses on the penchant that produces happy feelings. When they have recovered from their tiredness, and they return to work, their performance is better because the stress has been released and treated. Subsequently, in providing services to any customer, they will work more enthusiastically and in full of spirit.

In addition, leisure involvement affects other variables, namely job satisfaction. The effect given on job satisfaction is not big which is 0.284 , but enough to prove that the effect given is positive. Supported by previous research conducted by Suhartanto et al. (2018) which states that tourism involvement can affect employee's satisfaction on the job, and also job satisfaction can affect service performance.

Job satisfaction is an individual thing such as subjective wellbeing variable that corresponds to the values prevailing in each individual. The more aspects of the job that suit the individual's desire, the higher the level of perceived satisfaction is. If the company (restaurant) can give staff time to engage in leisure activities, they will feel that the company does not confine them in a job, thus there will be a sense of satisfaction with his or her current job.

The previous research conducted by Yeh (2013) also states that tourism involvement positively affects job satisfaction of the staff either directly, or mediated with other variables. The findings of this study have confirmed the current study and supported one of the theories expressed by Riggio (2005) that attempt which can be done to job satisfaction is giving the flexible job schedule. It does not mean that it is done freely, but the schedule can tolerate the priority that cannot be delayed, besides giving assurance or opportunity to give more free time to be with their relatives or friends. When the staff is satisfied with their job, they will yield good performance at work. This is because the staff does not feel burdened and will work responsibly. This finding is also supported by Suhartanto et al. (2018) who find similar results in their study that job satisfaction affects positively so as to improve service performance. 
The results of the test are also performed directly and the results even affect service performance with the greatest value among others. If examined in a theoretical point of view, this invention has supported some of the proposed theories and previous studies that have been done before. Unlike from a managerial point of view, this study explains the importance of frontline staff of the culinary industry to engage in leisure activities so that they can become happier and more prosperous, and are satisfied with the work they do, resulting in better service performance.

\section{LIMITATION AND FUTURE RESEARCH}

The results of the current research show that leisure activities are important for employees. Results of the wellbeing variable of the employees show they feel physically and mentally healthy, have a pleasant life, and feel that their lives are ideal for each individual's size. In addition, results of job satisfaction among the employees show good response as they are satisfied with their current work and are willing to keep working in the culinary industry. This is because by engaging in leisure activities, frontline staff will feel happy and will have freedom (subjective wellbeing) in their thoughts, body, and mentality that can lead to positive outcome.

Next is to do a path analysis to find out the interrelationships among the variables. From the results of the analysis described earlier, it can be concluded that the overall variables - leisure involvement, subjective wellbeing, and job satisfaction - have a positive influence on the service performance of frontline staff in culinary though with different levels of relation on each variable. Leisure involvement directly has a considerable influence on service performance of frontline staff, when viewed from any indicator, the average value is also good which means that frontline staff agrees if leisure activities are to be carried out apart from the work they do. It is recommended for culinary entrepreneurs who have employees to do "family gathering", provide "employee break room", and make employees aware of leisure importance by motivating them through inspiring brochures or posters.

The limitations of this study are related to the collection of data that may result in inconsistent dynamic relationships among the variables involved. Some of the possibilities that may occur can also be due to bad timing in which the respondent is asked to answer the questionnaire during the time when his emotions is unstable or he is not satisfied with his work, thus resulting in a biased results. Therefore, the interpretation of this study is limited. To overcome this, the future research can be designed to be more accurate so that the results can be compared. Another limitation is the sample of frontline staff culinary in Bandung. There will be a possibility of different perceptions about the culinary business from frontline staff elsewhere. For a more general consideration of the effect of leisure involvement on service performance, further studies may take samples from other fields or industries investigating other types of variables.

\section{REFERENCES}

Agmasari, S. (2018, February 6). Kompas: Travel. Retrieved from Kompas.com: https://travel.kompas.com/read/2018/02/o6/185000027/industri-kuliner-penopang-tertinggiperekonomian-kreatif-di-indonesia

Anderson, J. C., \& Gerbing, D. W. (1988). Structural equation modeling in practice: A review and recommended two-step approach. . Psychological Bulletin, 103(3), , 1390-1395.

Balatsky, G., \& Diener, E. (1993). Subjective wellbeing among Russian students. Journal of social indicators research, 28, 225-243. doi:https://doi.org/10.1007/BFo1079019 
Borman, W. C., \& Motowidlo, S. J. (1993). Expanding the criterion domain to include elements of contextual performance. . San Francisco,: CA: Jossey-Bass.

Borucki, C. C., \& Burke, M. J. (1999). An examination of service-related antecedents to retail store performance. Journal of Organizational Behavior, 2o(6), 943-962.

Bowen, J., \& Ford, R. C. (2004). What experts say about managing hospitality service delivery systems. International Journal of Contemporary Hospitality Management, 16(7), 394 - 401. doi:https://doi.org/10.1108/09596110410

BPS, K. B. (2018, May 9). Jumlah Restoran/Rumah Makan di Kota Bandung Tahun 2016. Retrieved from Badan Pusat Statistika Kota Bandung:

https://bandungkota.bps.go.id/statictable/2017/o8/29/121/-jumlah-restoran-rumah-makan-dikota-bandung-2016.html

BPS, P. J. (2018, Maret 23). Jumlah Restoran/Rumah Makan Menurut Kabupaten/Kota di Provinsi Jawa Barat, 2013-2016. Retrieved from Badan Pusat Statistik :

https://jabar.bps.go.id/statictable/2018/03/23/472/jumlah-restoran-rumah-makan-menurutkabupaten-kota-.html

Chi, C., \& Gursoy, D. (2009). Employee satisfaction, customer satisfaction, and financial performance: An empirical examination. International Journal of Hospitality and Management, 28, 245-253. doi:10.1016/j.jhm.2008.08.003

DeNeve, \& Cooper. (1998). The happy personality: a meta-analysis of 137 personality traits and subjective well-being. Journal of Marketing Psyhcology, 197-229. doi:0033-2909/98/\$3.00

Dimanche, F., Havitz, M. E., \& Howard, D. R. (1993). Segmenting recreationists and tourists using involvement profiles. Journal of travel and tourism, 33-52. doi:10.1300/Jo73v01no4_03

Evani, F. S. (2017, September 23). Potensi Industri Kuliner Capai Rp 1.50o Triliun per Tahun. Retrieved from Berita Satu: http://www.beritasatu.com/bisnis/454122-potensi-industrikuliner-capai-rp-150o-triliun-per-tahun.html

Group., I. W. (2008, October 3). Personal wellbeing index - Adult: 4th Edition. Retrieved from Internatonal Wellbeing Group:

http://www.deakin.edu.au/research/acqol/instruments/wellbeing-index/pwi-adult-english.pdf

Hair, J. E., \& Sarstedt, M. (2014). A primer on partial least squares structural equation modeling (PLS-SEM). Los Angeles: Sage.

Hair, J. E., Hult, G. T., Ringle, C. M., \& Sarstedt, M. (2014). A Primer on Partial Least Squares Structural Equation Modeling (PLS-SEM). . Los Angeles: Sage.

Hartline, M. D., \& C, F. O. (1993). Service Quality Implementation: The Effects of Organizational Socialization and Managerial Actions on Customer-Contact Employee Behaviors. Technical Working Paper, 93-122.

Havitz, M. E., \& Dimanche, F. (1990). Propositions for guiding the empirical testing of the involvement construct in recreational and tourist context. Leisure Sciences 12, 179-196.

Havitz, M. E., \& Dimanche, F. (1990). Propositions for testing the involvement construct in recreational and tourism contexts. Leisure Science, 179-195.

Henderson, J. C. (2004). Food as tourism resources: a view from singapore. Tourism Recreation Research vol.29, 29-74.

Henseler, J., Ringle, C., \& Sinkovics, R. R. (2009). The use of partial least square path modeling in international marketing. Advances in International, 20, 277-319.

Hoffman, \& Bateson. (2011). Service Marketing: Concepts, Stategies, and Cases. Mason. SouthWestern: Cengage Learning.

Hoy, W. K., \& Miskel, C. G. (1996). Educational administration: Theory, research, and practice, 5th edition. New York: McGraw-Hill.

Indonesia, B. P. (2016, September 8). Data Restoran di Kota Bandung. Retrieved from Badan Pusat Statistik Bandung: https://bandungkota.bps.go.id/Subjek/view/id/16\#subjekViewTab1

Jernej, H., \& Mussap, A. J. (2010). Research Note: Leisure satisfaction and subjective wellbeing. Annals of Leisure Research, 13:4. doi:10.1080/11745398.2010.9686871 
Juniman, P. T. (2017, January 18). Gaya Hidup Masyarakat Menjadikan Bisnis Kuliner Menjanjikan. Retrieved from CNN Indonesia: https://www.cnnindonesia.com/gaya-hidup/20170118121405262-187137/gaya-hidup-masyarakat-menjadikan-bisnis-kuliner-menjanjikan

Kreitner, R., \& Kinicki, A. (2014). Organizational behavioral-Ed 5. Boston: Mc-Graw Hill.

Kyle, G. T., Absher, J. D., Norman, W., Hammitt, W. E., \& Jodice, L. (2007). A modified involvementscale. Leisure Studies 26(4), 399-427. doi:https://doi.org/10.1080/02614360600896668

Kyle, G., \& Mowen, A. (2005). An examination of the leisure involvement-agency commitment relationship. Journal of Leisure Research 37(3), 342. doi:https://doi.org/10.1080/00222216.2005.11950057

Laurent, G., \& Kapferer, J. N. (1985). Measuring consumer involvement profiles. Journal of Marketing Research, 41-53.

Lazuardi, M., \& Triadi, M. S. (2015). Rencana Pengembangan Kuliner Nasional 2015-2019. Jakarta: PT Republik Solusi.

Liao, H., \& Chuang, A. (2004). A multilevel investigation of factors influencing employee service performance and customer outcomes. Academy of Management Journal, 47(1), 41-58. doi:https://doi.org/10.5465/20159559

Locke, E. A. (1969). What is job satisfaction? . Organizational Behavior and Human Performance, 4(1), 309-336.

Long, L. M. (2004). Culinary Tourism. Kentucky: The University Press of Kentucky.

Lovelock, C., \& Wirtz, J. (2011). Service Marketing: People, Technology, Strategy. Canada: Pearson.

Lu, L., Lu, A. C., Gursoy, D., \& Neale, N. R. (2016). Work engagement, job satisfaction, and turnover intentions. International Journal of Contemporary Hospitality Management, 28(4), 737-761. doi:10.1108/IJCHM-07-2014-036o

Lucas, R. E., Clark, A. E., Georgellis, Y., \& E, D. (2003). Re-examining adaptation the set-point model of happiness: Reactions to changes in marital status. Journal of Personality and Social Psychology, 84, 527-539. doi:10.1037/0022-3514.84.3.527

MacLaurin, T. L. (2001). Food Safety in travel and tourism. Journal of Travel Research vol.39, 332333. doi:https://doi.org/10.1177/004728750103900316

Riggio, R., \& B, B. (2005). Transformational Leadership (2nd ed.). England: Psychology Press.

Rothschild, L. M. (1984). Perspective on involvement current problems and future directions. Advance in consumer research, 216-217.

Saks, A. M. (2006). Antecedents and consequences of employee engagement. Journal of Managerial Psychology,21, 6oo-619. doi:https://doi.org/10.1108/02683940610690169

Slatten, T., \& Mehmetoglu, M. (2011). Antecedents and effects of engaged frontline employees. Managing Service Quality: An International Journal, 21(1), 88-107. doi:https://doi.org/10.1108/o9604521111100261

Suhartanto, D., \& Brien, A. (2018). Multidimensional engagement and store performance: The perspective of frontline retail employees. International Journal of Productivity and Performance Management, 67(5), 809-824. doi: doi:10.1108/IJPPM-03-2017-0065.

Suhartanto, D., Dean, D., Nansuri, R., \& N. N. Triyuni. (2018). "The Link Between Tourism Involvement and Service Performance: Evidence from Frontline Retail Employees. Journal of Business Research, 130-137. doi:10.1016/J.jbursres.2017.10.039

Suhartanto, D., \& Noor, A. (2012). Customer Satisfaction in the Airline Industry: The Role of Service Quality and Price. Paper presented at the Asia Tourism Forum.

Watkins, M. (1986). The influence of involvement and information search on consumers's choice of depreciative behavior. Journal of Leisure Research, 323-340.

Yeh, C. M. (2013). Tourism involvement, work engagement and job satisfaction among frotline hotel employees. Annals of Tourism Research, 42, 214-239. doi.org/10.1016/j.annals.2013.02.002 